\author{
U.T. Mustapha ${ }^{1,2}$, E. Hincal ${ }^{1}$, A. Yusuf ${ }^{2,3}$, S. Qureshi ${ }^{4}$, \\ T. Sanlidag ${ }^{1}$, S.M. Muhammad ${ }^{1}$, B. Kaymakamzade ${ }^{1}$, N. Gokbulut ${ }^{1, *}$ \\ ${ }^{1}$ Near East University, TRNC, Nicosia, Turkey; \\ ${ }^{2}$ Federal University Dutse, Nigeria; \\ ${ }^{3}$ Biruni University, Istanbul, Turkey; \\ ${ }^{4}$ Mehran University of Engineering and Technology, Jamshoro, Pakistan \\ (E-mail: umartasiumustapha@yahoo.com,evren.hincal@neu.edu.tr,yusufabdullahi@fud.edu.ng, \\ sania.qureshi@faculty.muet.edu.pk,trsanlidag@yahoo.com,salisumuhammadmuhammad@gmail.com, \\ bilgen.kaymakamzade@neu.edu.tr,nezihal.gokbulut@neu.edu.tr)
}

\title{
Transmission dynamics and control strategies of COVID-19: a modelling study
}

\begin{abstract}
In this paper a mathematical model is proposed, which incorporates quarantine and hospitalization to assess the community impact of social distancing and face mask among the susceptible population. The model parameters are estimated and fitted to the model with the use of laboratory confirmed COVID-19 cases in Turkey from March 11 to October 10, 2020. The partial rank correlation coefficient is employed to perform sensitivity analysis of the model, with basic reproduction number and infection attack rate as response functions. Results from the sensitivity analysis reveal that the most essential parameters for effective control of COVID-19 infection are recovery rate from quarantine individuals $\left(\delta_{1}\right)$, recovery rate from hospitalized individuals $\left(\delta_{4}\right)$, and transmission rate $(\beta)$. Some simulation results are obtained with the aid of mesh plots with respect to the basic reproductive number as a function of two different biological parameters randomly chosen from the model. Finally, numerical simulations on the dynamics of the model highlighted that infections from the compartments of each state variables decreases with time which causes an increase in susceptible individuals. This implies that avoiding contact with infected individuals by means of adequate awareness of social distancing and wearing face mask are vital to prevent or reduce the spread of COVID-19 infection.
\end{abstract}

Keywords: COVID-19, mathematical modelling, basic reproduction number, transmission dynamics, sensitivity analysis.

\section{Introduction}

The coronavirus disease 2019 (COVID-19), previously recognized as "2019-nCoV", from the family of Coronaviridae, which includes the Middle East respiratory syndrome coronavirus (MERS-CoV) and the severe acute respiratory syndrome coronavirus (SARS-CoV), is a lethal virus that mostly transmits via human-to-human route [1-7]. The disease emerged from Wuhan, China, in late December 2019 and the outbreaks are still ongoing worldwide [8-15]. The disease can be transmitted from person-to-person through droplets when breathing, coughing or through contact with infected person [16]. During the early phase of the outbreak COVID-19 displayed comparable signs and symptoms with pneumonia, and spread throughout China and later to other part of the world [11, 12]. As of October 17, 2020, there were more than 39 million cases including over 1 million deaths of COVID-19 worldwide [1, 9, 11, 12]. Although COVID-19 displayed similar symptoms to MERS-CoV and SARS-CoV, the severity appears not as high as these two coronaviruses [2-4, 9, 17].

The natural reservoir of COVID-19 and intermediate host that at first spread the virus to humans (zoonotic transmission) have nevertheless now not been established $[1,5,18]$. Recent studies show that some animals such as bats, hedgehogs, pangolins and snakes are suspected to spread the virus to humans [2, 5, 9, 12], after which human-to-human transmissions continues through air droplets or contact with infected individual [2-4, 9, 18, 19]. The most common symptoms of COVID-19 include respiratory disorder, fever, common cold, cough and pneumonia in severe cases $[3,4,20]$.

\footnotetext{
${ }^{*}$ Corresponding author.

E-mail: nezihal.gokbulut@neu.edu.tr
} 
As stated in [21], the latency period of the COVID-19 is found to be between 2-11 days that ought to be used in suggesting the time for quarantine of the exposed individual. Lately quite a few epidemiological modeling researches $[13,18,22,23]$ estimated the basic reproduction ratio and analysed the patterns of the virus in the early phase of the epidemic. Some of these latest researches $[13,18]$ found the estimated reproduction number to be extensively larger than unity which is a bit higher than that of MERS and SARS [24, 25]. It by implication shows that greater infections may additionally occur, which suggests that serious measures need to be taken to downsize the unfold of the virus. Zhao et al. [25] revealed that there is a sturdy affiliation between journey through train and the extend in the range of COVID-19 instances than journey via flight or road. Additionally, it is highlighted that ailment prevention and management measures are to be preferred for travelers by means of trains to curtail the COVID-19 spread. Also, Wu et al. [22] studied a meta-population compartmental model, which estimates and forecasts the COVID-19 outbreak, and recommended that the novel coronavirus infection can enlarge exponentially in more than one Chinese city with a lag time behind the Wuhan outbreak of about 1 to 14 days.

Motivated by some of these recent studies [13, 18, 22], in this paper a mathematical model is employed, which incorporates quarantine and hospitalization to explore the dynamical behavior of the COVID-19 transmission, and also to show the trends of its epidemics in order to notify policymakers and to suggest ways to curtail the spread of the virus.

The rest of the paper is organized in the following way: firstly, the model formulation is provided and the model analysis has been presented subsequently. Then, parameter estimation is presented. Afterwards, sensitivity analysis and numerical simulations are performed. Lastly, concluding remarks are given.

\section{Model formulation}

A new mathematical model is proposed to monitor the transmission dynamics of the novel corona virus (COVID-19). The total human population at time $t$, given by $N(t)$, is divided into sub-populations containing susceptible individuals $S(t)$, exposed individuals $E(t)$, individuals with mild infection $I_{1}(t)$, individuals with severe infection $I_{2}(t)$, asymptomatic individuals under quarantine $Q(t)$, hospitalized individuals $H(t)$, and recovered individuals $R(t)$, such that $N(t)=S(t)+E(t)+I_{1}(t)+I_{2}(t)+Q(t)+H(t)+R(t)$. The diagram of the model is given in Figure 1 to present the transmission between compartments.

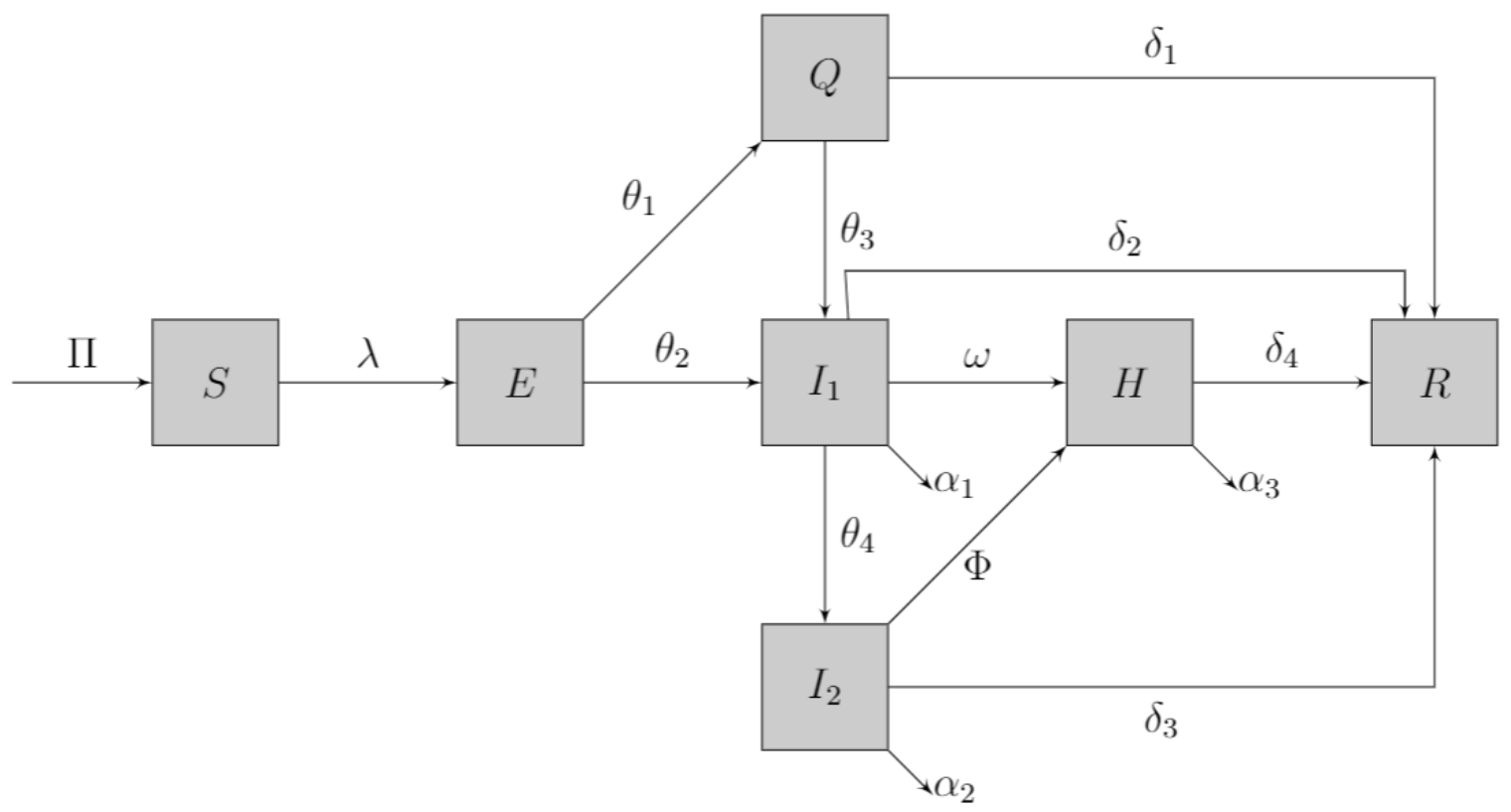

Figure 1. Flow diagram of COVID-19 model. 
The system is constructed as follows:

$$
\begin{aligned}
& \frac{d S}{d t}=\Pi-\lambda S, \\
& \frac{d E}{d t}=\lambda S-\left(\theta_{1}+\theta_{2}\right) E, \\
& \frac{d Q}{d t}=\theta_{1} E-\left(\delta_{1}+\theta_{3}\right) Q, \\
& \frac{d I_{1}}{d t}=\theta_{2} E+\theta_{3} Q-\left(\delta_{2}+\omega+\theta_{4}+\alpha_{1}\right) I_{1}, \\
& \frac{d I_{2}}{d t}=\theta_{4} I_{1}-\left(\Phi+\alpha_{2}+\delta_{3}\right) I_{2}, \\
& \frac{d H}{d t}=\omega I_{1}+\Phi I_{2}-\left(\delta_{4}+\alpha_{3}\right) H, \\
& \frac{d R}{d t}=\delta_{1} Q+\delta_{2} I_{1}+\delta_{3} I_{2}+\delta_{4} H,
\end{aligned}
$$

where $\lambda=\frac{\beta\left(\tau_{1} I_{1}+\tau_{2} I_{2}+\tau_{3} Q+\tau_{4} H\right)}{N}$ is the force of infection. The variables and parameters that are used in the model (1) are explained in Table 1 and Table 2, respectively.

Interpretation of the State Variables Used in the Model (1)

\begin{tabular}{|c|c|}
\hline Variables & Descriptions \\
\hline$N$ & Total population of individuals \\
\hline$S$ & Susceptible individuals at the risk of having COVID-19 infection \\
\hline$E$ & Exposed individuals \\
\hline$I_{1}$ & Infected individuals with mild infection \\
\hline$I_{2}$ & Infected individuals with severe infection \\
\hline$Q$ & Individuals under quarantine/isolated \\
\hline$H$ & Hospitalized individuals \\
\hline$R$ & Recovered individuals \\
\hline
\end{tabular}

Interpretation of the State Parameters Used in the Model (1)

\begin{tabular}{|c|c|}
\hline Parameters & Descriptions \\
\hline$\Pi$ & Recruitment rate \\
\hline$\beta$ & Transmission rate \\
\hline$\tau_{i}(i=1,2,3,4)$ & Parameters for increase/decrease on infectiousness in individuals \\
\hline$\theta_{i}(i=1,2,3,4)$ & Progression rates \\
\hline$\omega$ & Hospitalization rate from $I_{1}$ class \\
\hline$\varphi$ & Hospitalization rate from $I_{2}$ class \\
\hline$\alpha_{i}(i=1,2,3)$ & Disease induced death rates \\
\hline$\delta_{i}(1=1,2,3,4)$ & Recovery rates \\
\hline
\end{tabular}

Model analysis

The model is non-negative with respect to the human population, each of its parameters and state variables for each $t \geq 0$. Thus, one can easily prove that for each non-negative initial prerequisite the state variables of the model are non-negative.

Theorem 1. Let $\left(S, E, Q, I_{1}, I_{2}, H, R\right)$ be the solution to the system (1) with initial conditions $S \geq 0, E \geq 0$, $Q \geq 0, I_{1} \geq 0, I_{2} \geq 0, H \geq 0, R \geq 0$. Then, the set

$$
\Upsilon=\left\{\left(S, E, Q, I_{1}, I_{2}, H, R\right) \in R_{+}^{7} / S+E+Q+I_{1}+I_{2}+H+R \leq \Pi\right\}
$$

is invariant, positive, and all the solutions in $R_{+}^{7}$ stay in $\Upsilon$ with respect to (1). 
Proof. Addition of all of the system (1) gives

$$
\frac{d N}{d t}=\Pi-\alpha_{1} I_{1}-\alpha_{2} I_{2}-\alpha_{3} H
$$

so that, $\frac{d N}{d t} \leq \Pi$, and integrating both sides gives $N e^{t} \leq \Pi e^{t}+c$. By the use of theorem of Rota and Birkhoff regarding differential inequalities [26], we can easily obtain $0 \leq N \leq \Pi$ as $t \longrightarrow \infty$. Thus $N$ approaches $\Pi$ as $t \longrightarrow \infty$, and so the set of the solutions of the model (1) enters the region $\left\{\Upsilon=\left(S, E, Q, I_{1}, I_{2}, H, R\right) \in R_{+}^{7} / S \geq\right.$ $\left.\geq 0, E \geq 0, Q \geq 0, I_{1} \geq 0, I_{2} \geq 0, H \geq 0, R \geq 0, N \leq \Pi\right\}$, this guarantees the biological feasibility of the model (1).

Hence, it is enough to consider the model's dynamic in $\Upsilon$ [27].

\section{Stability of disease-free equilibrium}

The model exhibit a unique disease-free equilibrium point "DFE", which is obtained by equating the righthand sides of (1) to zero, then

$$
C^{0}=\left(S, E, Q, I_{1}, I_{2}, H, R\right)=(\Pi, 0,0,0,0,0,0)
$$

and it can clearly be seen that $C^{0}$ attracts the region, so that

$$
C^{0}=\left\{\left(S, E, Q, I_{1}, I_{2}, H, R\right) \in C^{0}: E=Q=I_{1}=I_{2}=H=R=0\right\} .
$$

The basic reproduction number $R_{0}$ is computed using the next generation matrix (NGM) method, which represents the number of secondary cases produced by an infected individual with COVID-19 infection throughout his/her entire period of infection in an absolutely susceptible population [27-31], which is given as follows:

$$
\begin{aligned}
& f=\left[\begin{array}{c}
\frac{\beta\left(\tau_{2} I_{1}+\tau_{3} I_{2}+\tau_{4} Q+\tau_{5} H\right)}{N} S_{o} \\
0 \\
0 \\
0 \\
0
\end{array}\right], v=\left[\begin{array}{c}
\left(\theta_{1}+\theta_{2}\right) E \\
-\theta_{1} E+\left(\delta_{1}+\theta_{3}\right) Q \\
-\theta_{2} E-\theta_{3} Q+\left(\delta_{2}+\omega+\theta_{4}+\alpha_{1}\right) I_{1} \\
-\theta_{4} I_{1}+\left(\varphi+\alpha_{2}+\delta_{3}\right) I_{2} \\
-\omega I_{1}-\varphi I_{2}+\left(\delta_{4}+\alpha_{3}\right) H
\end{array}\right], \\
& F=\left[\begin{array}{ccccc}
0 & \beta \tau_{1} & \beta \tau_{2} & \beta \tau_{3} & \beta \tau_{4} \\
0 & 0 & 0 & 0 & 0 \\
0 & 0 & 0 & 0 & 0 \\
0 & 0 & 0 & 0 & 0 \\
0 & 0 & 0 & 0 & 0
\end{array}\right], V=\left[\begin{array}{ccccc}
k_{1} & 0 & 0 & 0 & 0 \\
-\theta_{1} & k_{2} & 0 & 0 & 0 \\
-\theta_{2} & -\theta_{3} & b_{1} & 0 & 0 \\
0 & 0 & -\theta_{4} & b_{2} & 0 \\
0 & 0 & -\omega & -\varphi & k_{3}
\end{array}\right]
\end{aligned}
$$

where $k_{1}=\left(\theta_{1}+\theta_{2}\right), k_{2}=\left(\delta_{1}+\theta_{3}\right), k_{3}=\left(\delta_{4}+\alpha_{3}\right) b_{1}=\left(\delta_{2}+\omega+\theta_{4}+\alpha_{1}\right), b_{2}=\left(\varphi+\alpha_{2}+\delta_{3}\right)$. Then $V^{-1}$ is obtained as

$$
V^{-1}=\left[\begin{array}{ccccc}
k_{1}{ }^{-1} & 0 & 0 & 0 & 0 \\
\frac{\theta_{1}}{k_{2} k_{1}} & k_{2}^{-1} & 0 & 0 & 0 \\
\frac{\theta_{2} k_{2}+\theta_{3} \theta_{1}}{b_{1} k_{2} k_{1}} & \frac{\theta_{3}}{b_{1} k_{2}} & b_{1}^{-1} & 0 & 0 \\
\frac{\theta_{4}\left(\theta_{2} k_{2}+\theta_{3} \theta_{1}\right)}{b_{2} b_{1} k_{2} k_{1}} & \frac{\theta_{4} \theta_{3}}{b_{2} b_{1} k_{2}} & \frac{\theta_{4}}{b_{2} b_{1}} & b_{2}^{-1} & 0 \\
\frac{\left(\theta_{2} k_{2}+\theta_{3} \theta_{1}\right)\left(\omega b_{2}+\varphi \theta_{4}\right)}{k_{1} k_{2} b_{1} b_{2} k_{3}} & \frac{\theta_{3}\left(\omega b_{2}+\varphi \theta_{4}\right)}{b_{2} b_{1} k_{2} k_{3}} & \frac{\omega b_{2}+\varphi \theta_{4}}{b_{2} b_{1} k_{3}} & \frac{\varphi}{b_{2} k_{3}} & k_{3}^{-1}
\end{array}\right] .
$$

Thus, the basic reproduction number $R_{0}=\rho\left(F V^{-1}\right)$ equals to 


$$
R_{0}=\frac{\left(\left(\left(b_{1} \beta \tau_{1}+\beta \tau_{2} \theta_{3}\right) \theta_{1}+\beta \tau_{2} k_{2} \theta_{2}\right) k_{3}+\omega \beta \tau_{4}\left(\theta_{2} k_{2}+\theta_{3} \theta_{1}\right)\right) b_{2}+\theta_{4}\left(\beta \tau_{4} \varphi+\beta \tau_{3} k_{3}\right)\left(\theta_{2} k_{2}+\theta_{3} \theta_{1}\right)}{k_{1} k_{2} k_{3} b_{1} b_{2}},
$$

with $S_{0}=N$ and $\rho$ symbolizing the next generation matrix's spectral radius. Following [27], relying on the local stability of the disease-free equilibrium of the model (1), the theorem below is arrived.

Theorem 2. For the model (1) the disease-free equilibrium is locally asymptotically stable whenever $R_{0}<1$ and unstable if $R_{0}>1$.

Proof. The Jacobian matrix evaluated at $\mathcal{C}^{0}$, denoted by $J_{0}$ is

$$
J\left(C^{0}\right)=\left(\begin{array}{ccccccc}
-\lambda & 0 & 0 & 0 & 0 & 0 & 0 \\
\lambda & -\theta_{1}-\theta_{2} & 0 & 0 & 0 & 0 & 0 \\
0 & \theta_{1} & -\delta_{1}-\theta_{3} & 0 & 0 & 0 & 0 \\
0 & \theta_{2} & \theta_{3} & -\delta_{2}-\omega-\theta_{4}-\alpha_{1} & 0 & 0 & 0 \\
0 & 0 & 0 & \theta_{4} & -\varphi-\alpha_{2}-\delta_{3} & 0 & 0 \\
0 & 0 & 0 & \omega & \varphi & -\delta_{4}-\alpha_{3} & 0 \\
0 & 0 & \delta_{1} & \delta_{2} & \delta_{3} & \delta_{4} & 0
\end{array}\right) .
$$

Then, the eigenvalues of this matrix are $0,-\theta_{1}-\theta_{2},-\delta_{1}-\theta_{3},-\delta_{4}-\alpha_{3},-\varphi-\alpha_{2}-\delta_{3},-\delta_{2}-\omega-\theta_{4}-\alpha_{1}$, and $-\lambda$, which are obtained by deleting the first row and the first column of $J_{0}$ as well as its last row and the last column. Thus, the DFE, $C^{0}$ is locally asymptotically stable if $R_{0}<1$ and unstable if $R_{0}>1$. Hence, the proof is complete.

\section{Parameter estimation}

This section explains the fitting of parameters involved in the proposed COVID-19 model based upon the real cases of the pandemic throughout Turkey. Daily cases of the pandemic are taken between March 11-October 10, 2020, while preparing this research paper. For initial conditions the total population of Turkey is noted to be $N(0)=83.3 \times 10^{6}$, the initial exposed and quarantined population is taken as $E(0)=Q(0)=3 \times 10^{6}$ and this helped us to determine rest of the initial values for the state variables using the relation $N(0)=S(0)+E(0)+Q(0)+I_{1}(0)+I_{2}(0)+H(0)+R(0)$. In this connection, $S(0)=78338132, I_{1}(0)=300$, $I_{2}(0)=470, H(0)=150$, and $R(0)=15$ are obtained. There are 19 biological parameters which have been estimated with the aid of least-square fitting method leading to produce a best fit of the COVID-19 model's solution to the real pandemic cases as depicted in the Figure 2. By reducing the average absolute relative error between the real COVID-19 cases and the solution of the model, the best values of the biological parameters are obtained. The objective function yields to relatively small error having the value $9.8748 \times 10^{-2}$. The Figure 2 shows the real COVID-19 cases by red solid squares whereas the best fitted curve of the model is shown by the black solid line. The biological parameters included in the model are listed in Table 3 along with their best estimated values obtained via least-squares technique. These parameters have finally produced the value of the basic reproduction number equivalent to $\mathcal{R}_{0}=2.82$ for the real COVID-19 cases in Turkey from March 11 to October 10, 2020.

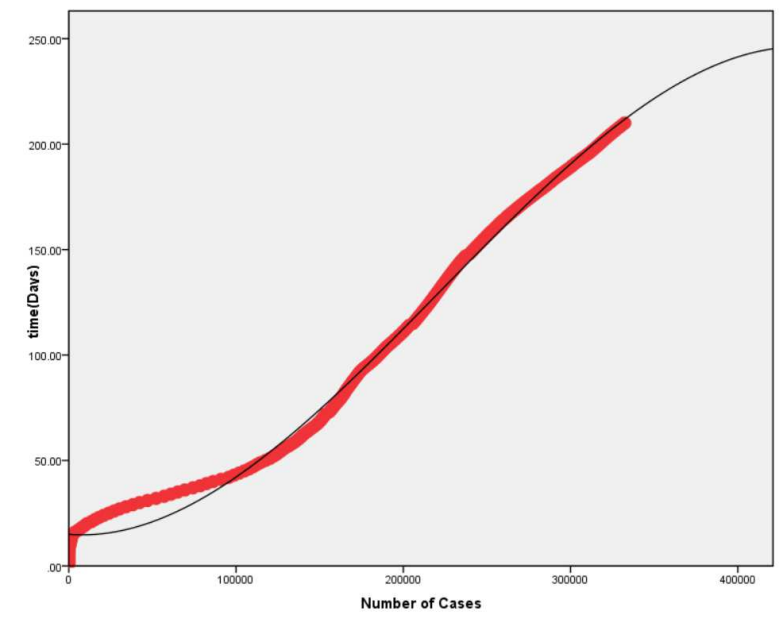

Figure 2. Data fitting for the real COVID-19 cases in Turkey from March 11 to October 10, 2020 
Sensitivity analysis

Table 3

Baseline Values of the Parameters Used in (1)

\begin{tabular}{|c|c|c|c|}
\hline Parameter & Value & Units/Remarks & Sources \\
\hline$N(0)$ & Turkey & Constant & {$[32]$} \\
\hline$S(0)$ & $0.95 \times N(0)$ & Constant & Assumed \\
\hline$\Pi$ & 9.9991 & Day $^{-1}$ & Fitted \\
\hline$\beta$ & 0.641 & Day $^{-1}$ & Assumed \\
\hline$\tau_{1}$ & 0.647 & Day $^{-1}$ & Assumed \\
\hline$\tau_{2}$ & 0.456 & Day $^{-1}$ & Assumed \\
\hline$\tau_{3}$ & 0.567 & Day $^{-1}$ & Assumed \\
\hline$\tau_{4}$ & 0.334 & Day $^{-1}$ & Assumed \\
\hline$\alpha_{1}$ & 0.0378 & Day $^{-1}$ & Fitted \\
\hline$\alpha_{2}$ & 0.0 .0324 & Day $^{-1}$ & Fitted \\
\hline$\alpha_{3}$ & 0.0289 & Day $^{-1}$ & Fitted \\
\hline$\Phi$ & 0.00213 & Day $^{-1}$ & $\begin{array}{c}\text { Estimated } \\
\text { by [32] }\end{array}$ \\
\hline$\omega$ & 0.00004 & Day $^{-1}$ & $\begin{array}{c}\text { Estimated } \\
\text { by [32] }\end{array}$ \\
\hline$\delta_{1}$ & 0.24 & Day $^{-1}$ & Fitted \\
\hline$\delta_{2}$ & 0.133 & Day $^{-1}$ & Fitted \\
\hline$\delta_{3}$ & 0.00389 & Day $^{-1}$ & Fitted \\
\hline$\delta_{4}$ & 0.00527 & Day $^{-1}$ & Fitted \\
\hline$\theta_{1}$ & 0.632 & Day $^{-1}$ & Fitted \\
\hline$\theta_{2}$ & 0.0034 & Day $^{-1}$ & Fitted \\
\hline$\theta_{3}$ & 0.0023 & Day $^{-1}$ & Fitted \\
\hline$\theta_{4}$ & 0.00512 & Day $^{-1}$ & Fitted \\
\hline
\end{tabular}

Since parameters of an epidemiological system are either evaluated or fitted along these lines are conveying some vulnerability with respect to their qualities utilized for reaching conclusions about the fundamental pestilence. Consequently, it is essential to survey the singular effects of every parameter on the dynamics of the pestilence, subsequently finding the parameters with the most significant impact towards decrease or diminishing the scourge. In the current study we employed a partial rank correlation coefficients (PRCCs) of the basic reproduction number and attack rate to investigate the most significant parameters for curbing the dissemination of COVID-19 in a community. Here, the most effective parameters are recovery rate from isolated people $\delta_{1}$, recovery rate from hospitalized people $\delta_{4}$, and transmission rate $(\beta)$ [33-37].

Furthermore, since the basic reproductive number $R_{0}$ is the most important quantity to comprehend the extent for the spread of an epidemic, $R_{0}$ has been investigated by varying different kinds of biological parameters of the proposed COVID-19 model. Using mesh plot and the parameter values in Table 3, some numerical results are obtained. The results as depicted in Figure 4 showed a significant increase with the variation in the progression rates of asymptomatic individuals under quarantine to the mild infection $\theta_{3}$ and that of mild infection individuals to the severe infection $\theta_{4}$, while $R_{0}$ decreases/increases with the decreasing/increasing value of transmission rate $\beta$ and the rate of increase of infectiousness in human $\tau_{4}$ and increases with decrease of recovery rates from isolated people $\delta_{1}$, mild infection individuals $\delta_{2}$, severe infection individuals $\delta_{3}$, and hospitalized individuals $\delta_{4}$. 

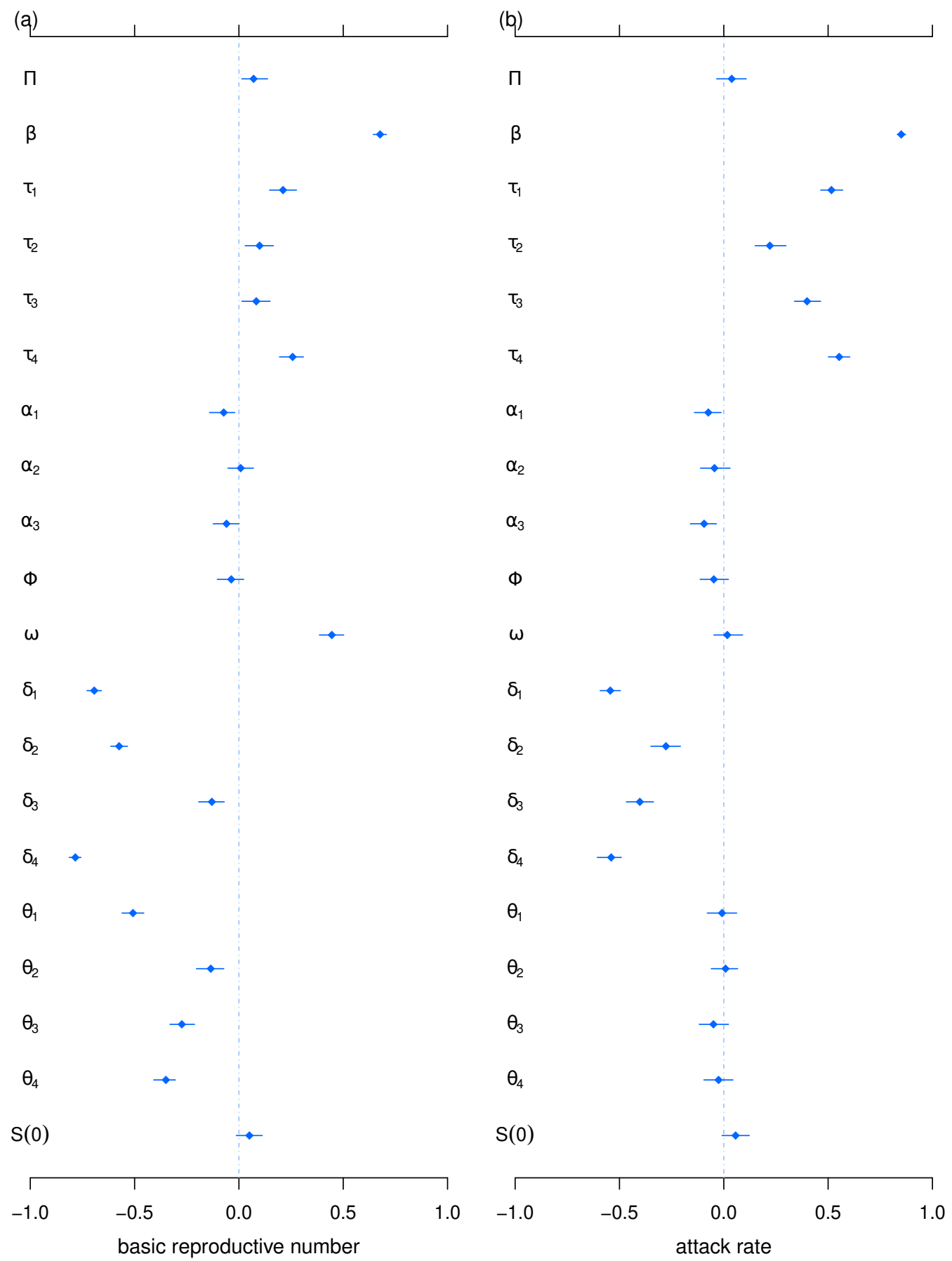

Figure 3. The partial rank correlation coefficient of the basic reproduction number $R_{0}$ with respect to model parameters. The dots are the estimated correlation and the bars represent the $95 \%$ confidence interval.

The parameter values used for sensitivity analysis are summarised in Table 3

\section{Numerical simulations}

This is the position in which we got a deep insight into the complex behavior of the model. The present section provided the model's numerical simulations while using the biological parameters as previously mentioned. The Euler technique is used to get the solution of the proposed model and to obtain the graphical results based on parameters that are taken in Table 3. 

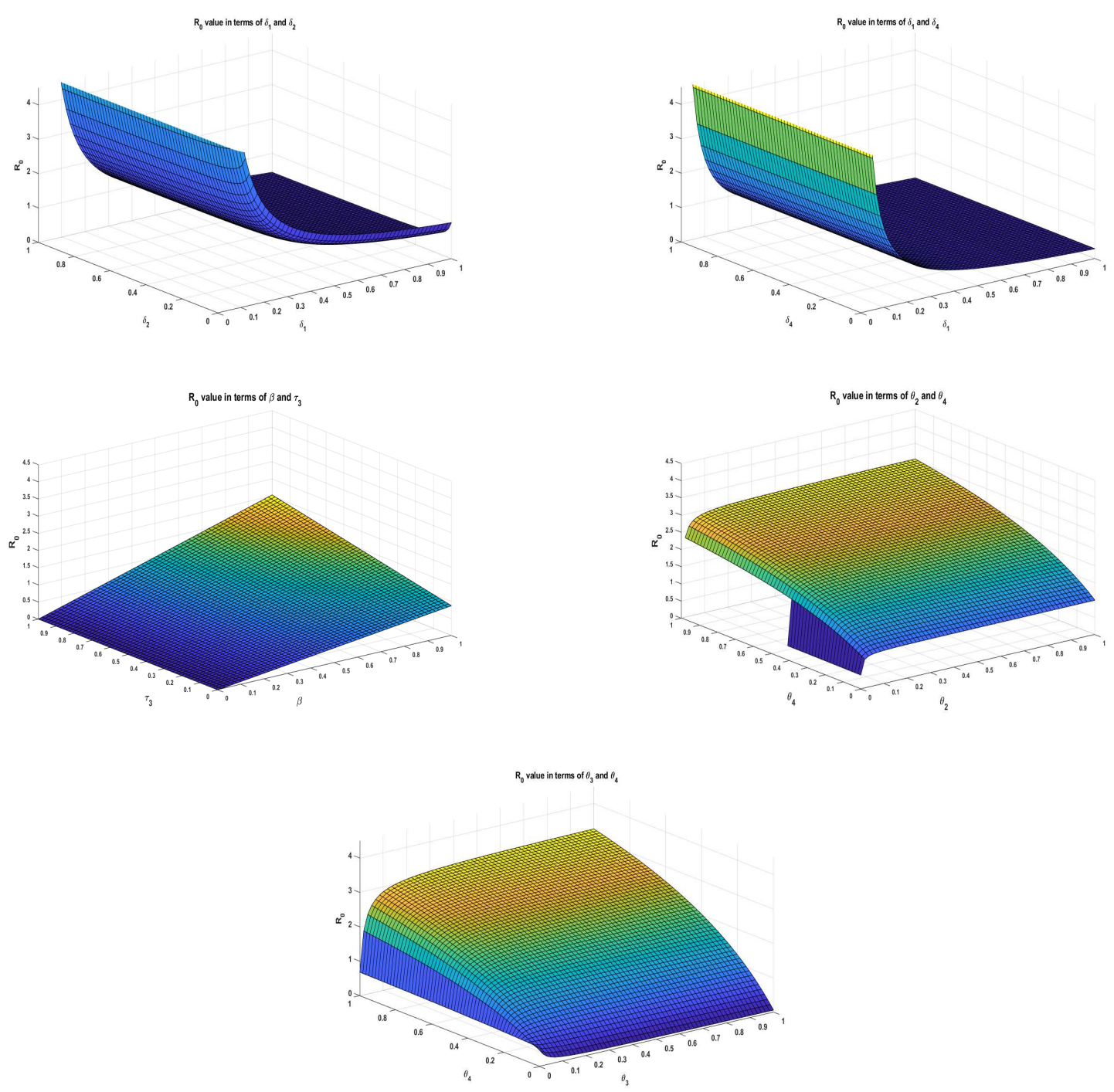

Figure 4. Mesh grid plots of the basic reproduction number in terms of the controllable parameters with basic reproduction number $R_{0}$ as a response function

In the absence of an exact solution for the proposed model we need to establish an approximate solutions to show the behaviour of the model. With this purpose we employ one of the effective numerical scheme called Euler method. The method is as follows: assume that a well-posed initial-value condition is given by

$$
\frac{d y}{d t}=f(t, y), a \leq t \leq b \text { and } y(a)=\chi .
$$

A sequence of approximation point $(t, w) \approx(t, y(t))$ is established by Euler method to the exact solutions of ODE by $t_{i+1}=t_{i}+h$ and $w_{i+1}=w_{i}+h f\left(t_{i}, w_{i}\right), i=0,1, \ldots, N-1$, and $t_{0}=a, w_{0}=\alpha, h=\frac{b-a}{N}$.

The following figures are obtained by using the MATLAB version R2020a and the parameter values from Table 3. From the Figure 5 it is observed that there is a significant decrease in both the compartments of exposed individuals, isolated/quarantined individuals, infected individuals with mild infection, individuals with severe infections and hospitalized individuals while the susceptible and recovery compartments increases. These signified that the estimated parameter values taking from Table 3 gives the required results in controlling the spread of COVID-19 infection. The results depicted in Figures 6, 7, 8, and 9 with the decreasing/increasing values of $\lambda$ (force of infection) showed that adequate awareness of social distancing and wearing of face masks in most vulnerable communities play significant role in the spread of the COVID-19 infection. 

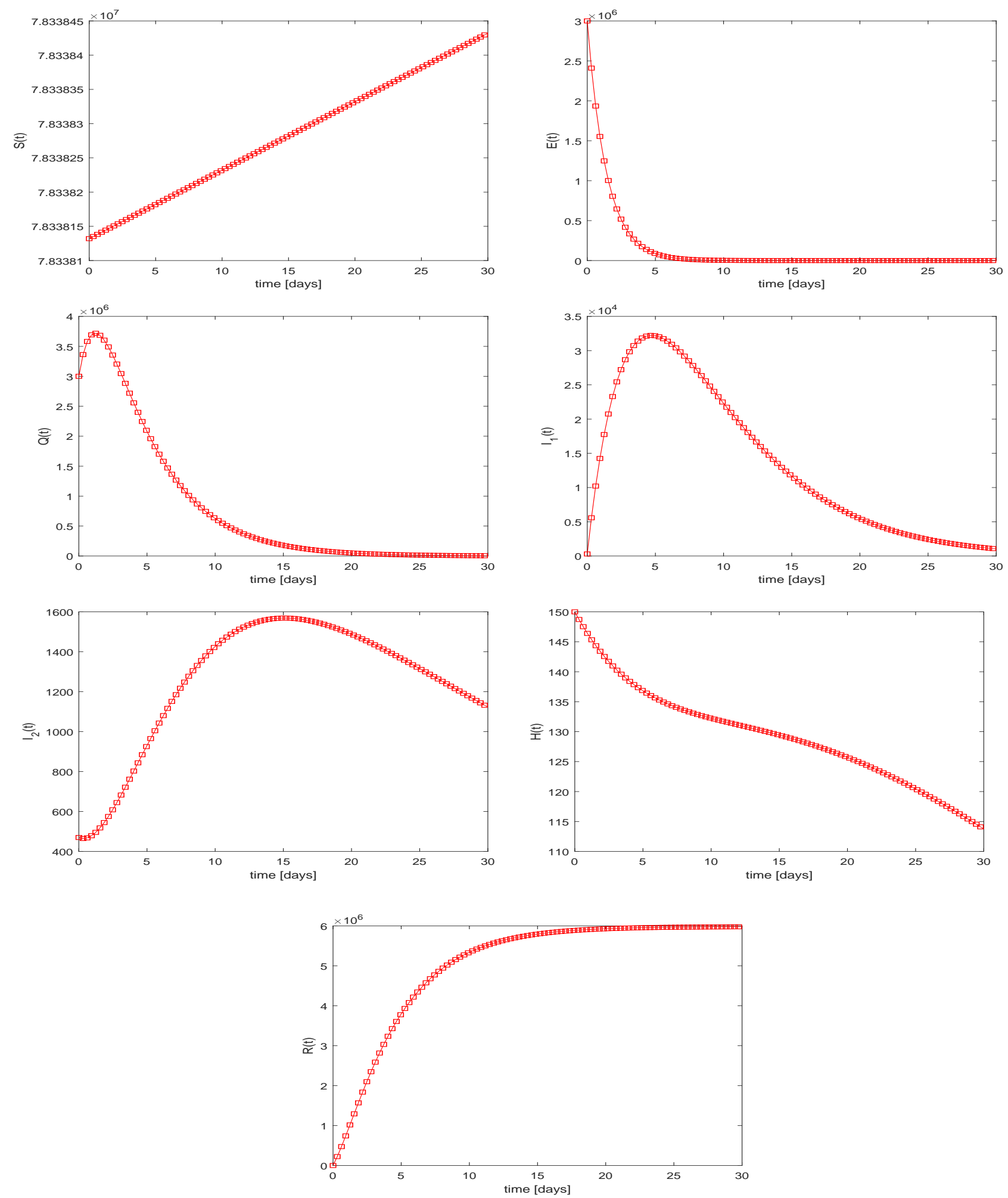

Figure 5. Dynamical behavior of each state variables of the proposed model (1) while taking parameters' values from the Table 3 


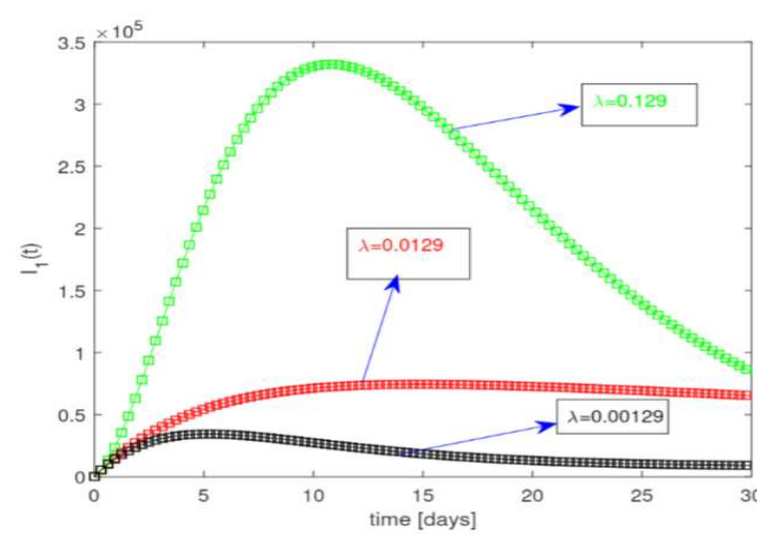

(a)

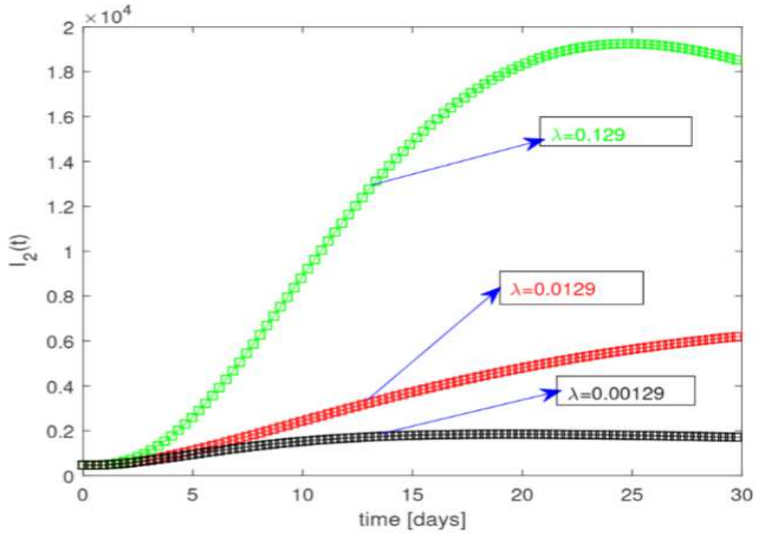

(b)

Figure 6. (a) Profile of $I_{1}$ (individuals with mild infection) and (b) profile of $I_{2}$ (individuals with severe infection), with decreasing values of $\lambda$ (force of infection).

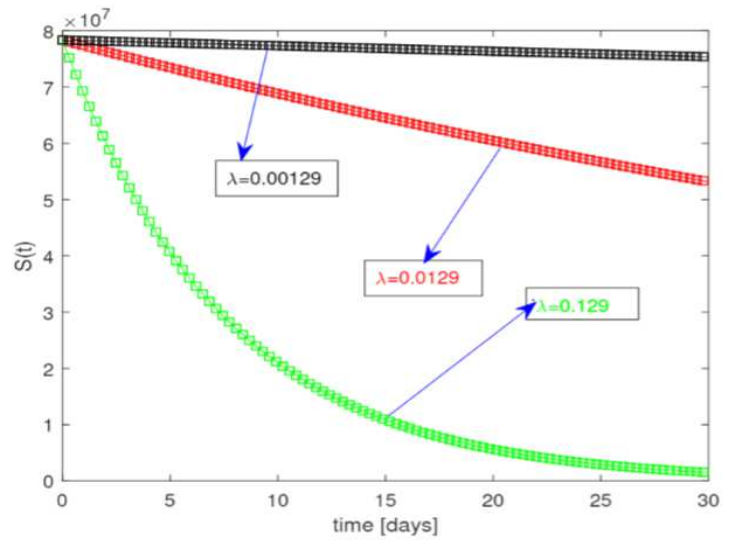

(a)

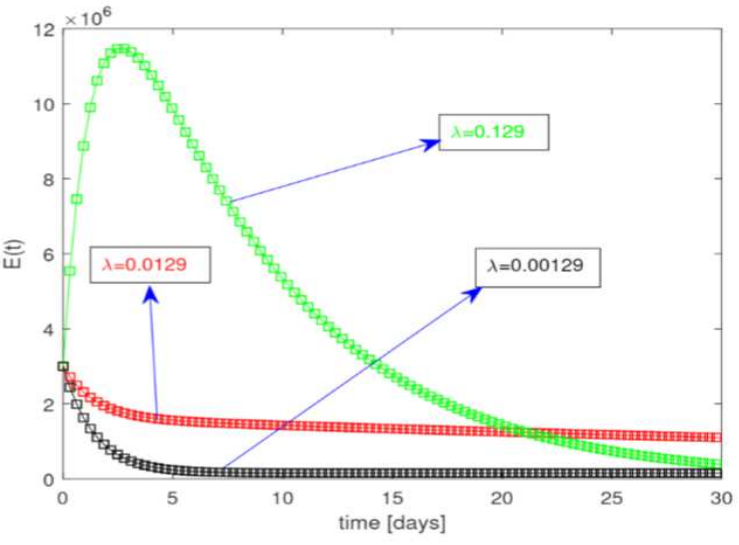

(b)

Figure 7. (a) Profile of $S$ (susceptible individuals) and (b) profile of $E$ (exposed individuals), with decreasing values of $\lambda$ (force of infection).

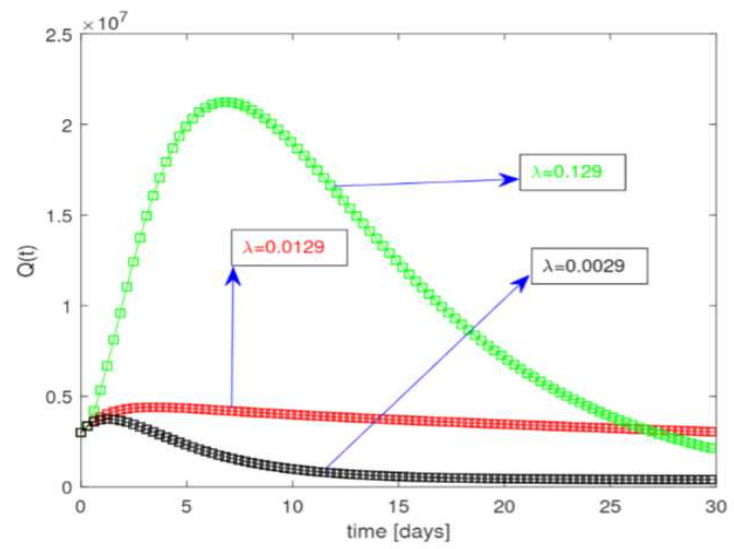

(a)

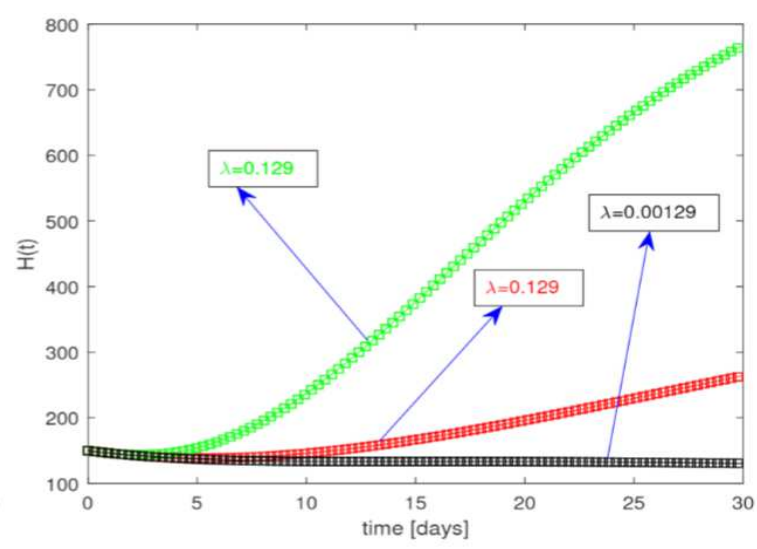

(b)

Figure 8. (a) Profile of $Q$ (quarantined individuals) and (b) profile of $H$ (hospitalized individuals), with increasing values of $\lambda$ (force of infection) 


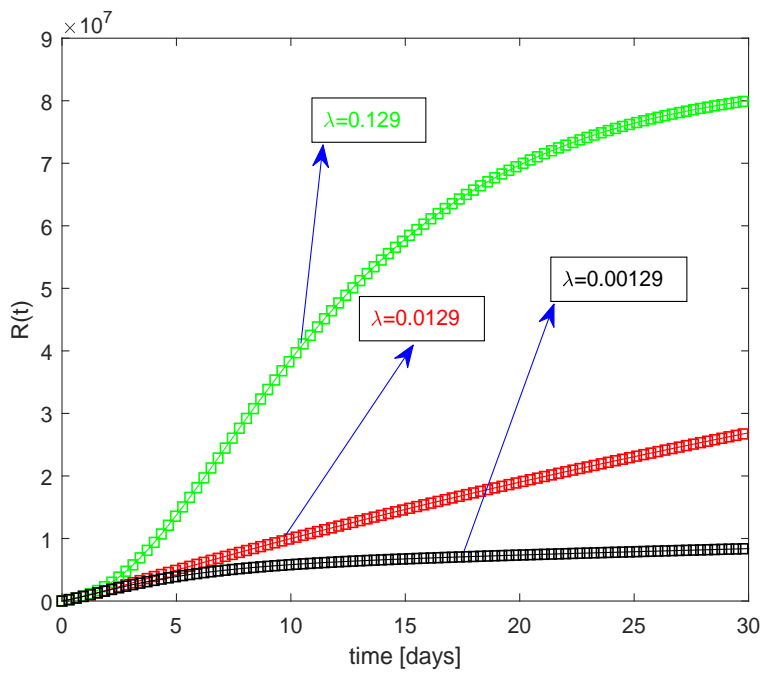

Figure 9. Profile of $R$ (recovered individuals) with increasing values of $\lambda$ (force of infection).

\section{Conclusion}

In this paper a mathematical model is proposed, which incorporates quarantine and hospitalization to study the dynamical behavior of the COVID-19 transmission. The parameters of the model are estimated and fitted to the model with the use of laboratory confirmed COVID-19 data cases of Turkey from March 11 to October 10, 2020, using least-square fitting method. The threshold quantity known as basic reproduction number is obtained by using the next generation matrix techniques. Some simulation results are obtained with the aid of mesh plots for the reproductive number as a function of two different biological parameters. Using partial rank correlation coefficients of the basic reproduction number and infection attack rate as a response functions, we revealed the most essential parameters for effectively controlling the COVID-19 infection. It is found that the epidemiological parameters that should be given emphasis in controlling the spread of COVID-19 are the recovery rate from quarantine individuals $\delta_{1}$, recovery rate from hospitalized individuals $\delta_{4}$ and transmission rate $(\beta)$. Finally, numerical simulations on the dynamics of the model showed that the infections in the compartments of each state variables decreases with time which causes an increase in susceptible individuals. This implies that avoiding contact with infected individuals by means of adequate awareness of social distancing and wearing of face mask are vital to prevent or reduce the spread of COVID-19 infection.

Furthermore, it should also be emphasized that the present research study will be strengthened in future research by analyzing and investigating the modern fractional operators and optimal control strategies. To the unknown characters and characteristics of this pandemic of COVID-19 this is a significant and decisive step remaining to be accomplished.

\section{References}

1 Imai, N., Dorigatti, I., Cori, A., Riley, S., \& Ferguson, N.M. (2020). Estimating the potential total number of novel Coronavirus (2019-nCoV) cases in Wuhan city, China. Preprint published by the Imperial College London. Retrieved from https://www.imperial.ac.uk/mrc-global-infectious-disease-analysis/news-wuhan coronavirus/.

2 Ji, W., Wang, W., Zhao, X., Zai, J., \& Li, X. (2020). Homologous recombination within the spike glycoprotein of the newly identified coronavirus may boost cross-species transmission from snake to human. Journal of Medical Virology, 92(4), 433-440.

3 Huang, C., Wang, Y., Li, X., Ren, L., Zhao, J., Hu, Y., et. al. (2020). Clinical features of patients infected with 2019 novel coronavirus in Wuhan, China. Lancet, 395(10223), 497-506.

4 Chan, J.F., Yuan, S., Kok, K., To, KK., Chu, H., Yang, J., et. al. (2020). A familial cluster of pneumonia associated with the 2019 novel coronavirus indicating person-to-person transmission: a study of a family cluster. Lancet, 395 (10223), 15-21.

5 Lui, S., \& Saif, L. (2020). Emerging viruses without borders: The Wuhan coronavirus. Viruses, 12(2). 
6 Gilbert, M., Pullano, G., Pinotti, F., Valdano, E., et. al. (2020). Preparedness and vulnerability of African countries against importations of COVID-19: a modelling study. Lancet, 395(10227), 871-877.

7 Musa, S.S., Zhao, S., Wang, M.H., Habib, A.G., et. al. (2020). Estimation of exponential growth rate and basic reproduction number of the coronavirus disease 2019 (COVID-19) in Africa. Infect. Dis. Poverty, $9(96)$.

8 World Health Organization, Novel coronavirus (2019-nCoV). Retrieved from https://www.who.int /emerge ncies/diseases/novel-coronavirus-2019.

9 World Health Organization, Laboratory testing for 2019 novel coronavirus (2019-nCoV) in suspect ed human cases. Retrieved from https://www.who.int/health-topics/coronavirus/laboratorydiagn ostics-fornovel-coronavirus.

10 World Health Organization, WHO Director-General's remarks at the media briefing on 2019-nCoV on 11 February 2020. Retrieved from https://www.who.int/dg/speeches/detail/who-direct or-general-sremarks-at-the-media-briefing-on-2019-ncov-on-11-february-2020.

11 World Health Organization, Novel Coronavirus (2019-nCoV) situation reports. Retrieved from https://ww w.who.int/emergencies/diseases/novel-coronavirus-2019/situation-reports/.

12 National Health Commission of the People's Republic of China, Situation report of the pneumonia cases caused by the novel coronavirus. Retrieved from http:www.nhc.gov.cn/yjb/s3578/202001 /a3c8b514406741 7889d8760254b1a7ca.shtml.

13 Zhao, S., Lin, Q., Ran, J., Musa, S.S., et. al. (2020). Preliminary estimation of the basic reproduction number of novel coronavirus (2019-nCoV) in China, from 2019 to 2020: A data-driven analysis in the early phase of the outbreak. Int. J. Infec. Dis., 92, 214-217.

$14 \mathrm{Wu}$, P., Hao, X., Lau, E.H.Y., Wong, J.Y., et. al. (2020). Real-time tentative assessment of the epidemiological 136 characteristics of novel coronavirus infections in Wuhan, China, as at 22 January 2020. Eurosurveillance, 25(3).

15 Zhao, S., Musa, S.S., Lin, Q., Ran, J., et. al. (2020). Estimating the unreported number of novel coronavirus (2019-nCoV) Cases in China in the first half of january 2020: a data-driven modelling analysis of the early outbreak. J. Clin. Med., 9(2), 388 .

16 Centers for Disease Control and Prevention, How 2019-nCoV Spreads. Retrieved from https://www.cdc.go $\mathrm{v} /$ coronavirus/2019-ncov/about/transmission.html.

17 World Health Organization, The collection of the Disease Outbreak News (DONs). Retrieved from https://www.who.int/csr/don/en/.

18 Read, J.M., Bridgen, J.R.E., Cummings, D.A.T., Ho, A., \& Jewell, C.P. (2020). Novel coronavirus 2019$\mathrm{nCoV}$ : early estimation of epidemiological parameters and epidemic predictions. medRxiv, https://doi.org /10.1101/2020.01.23.20018549.

19 World Health Organization, twitter post on 21 Jan 2020. Retrieved from https://twitter.com/WH OWPRO /status/1219478547644813312s=20.

20 World Health Organization, Pneumonia of unknown cause -China. Retrieved from https://www.w ho.int/csr/don/05-january-2020-pneumonia-of-unkown-cause-china/en/

21 Backer, J.A., Klinkenberg, D., \& Wallinga, J. (2020). Incubation period of 2019 novel coronavirus (2019$\mathrm{nCoV}$ ) infections among travellers from Wuhan, China, 20-28 January 2020 . Euro Surveill., 25(5).

$22 \mathrm{Wu}$, J.T., Leung, K., \& Leung, G.M. (2020). Nowcasting and forecasting the potential domestic and international spread of the 2019-nCoV outbreak originating in Wuhan, China: a modelling study . Lancet, $395(10225), 689-697$.

23 Zhao, S., Zhuang, Z., Ran, J., Lin, J., et. al. (2020). The association between domestic train transportation and novel coronavirus (2019-nCoV) outbreak in China from 2019 to 2020: A data-driven correlational report. Travel Medicine and Infectious Disease, 33.

24 Lipsitch, M., Cohen, T., Cooper, B., Robins, J.M., et. al. (2003). Transmission dynamics and control of severe acute respiratory syndrome. Science, 300(5627), 1966-1970.

25 World Health Organization, Consensus document on the epidemiology of severe acute respiratory syndrome. Retrieved from https://apps.who.int/iris/handle/10665/70863.

26 Birkhoff, G., \& Rota G.C. (1982). Ordinary Differential Equations. Ginn. 
27 Driessche, P. \& Watmough, J. (2002). Reproduction numbers and sub-threshold endemic equilibria for compartmental models of disease transmission. Math. Biosci., 180(1-2), 29-48.

28 Musa, S.S., Zhao, S., Chan, H.S., Jin, Z., \& He, D. (2019). A mathematical model to study the 2014-2015 large-scale dengue epidemics in Kaohsiung and Tainan cities in Taiwan, China. Math. Biosci. Eng., 16(5), $3841-3863$.

29 Mustapha, U.T., \& Hincal, E. (2020). An optimal control of hookworm transmissions model with differential infectivity. Physica A: Statistical Mechanics and its Applications, 545.

30 Diekmann, O., Heesterbeek, J.A.P., \& Metz, J.A.J. (1990). On the definition and the computation of the basic reproduction ratio, $R_{0}$, in models for infectious diseases in heterogeneous populations. J. Math. Biol., 28, 365-382.

31 News release in South China Morning Post on 26 January 2020. Retrieved from https://www.scmp .com/ news/china/society/article/3047676/number-coronavirus-cases-china-doubles-spread-rate-accelerates.

32 Agusto, F.B., Teboh-Ewungkem, M.I., \& Gumel, A.B. (2015). Mathematical assessment of the effect of traditional beliefs and customs on the transmission dynamics of the 2014 Ebola outbreaks. BMC Medicine, 13.

33 Gao, D., Lou, Y., He, D., Porco, T.C., et. al. (2016). Prevention and control of zika as a mosquito-borne and sexually transmitted disease: a mathematical modeling analysis. Scient. reports, 6 .

34 Musa, S.S., Zhao, S., Hussaini, N., Habib, A.G., He, D. (2020). Mathematical modeling and analysis of Meningococcal Meningitis transmission dynamics. Int. J. Biomath., 13(01).

35 Trotter, C.L., Gay, N.J., \& Edmunds, W.J. (2005). Dynamic models of meningococcal carriage, disease, and the impact of serogroup C conjugate vaccination. Am. J. Epidemiol., 162(1), 89-100.

36 Xiao, Y., Tang, S., \& Wu, J. (2015).Media impact switching surface during an infectious disease outbreak. Scient. reports, 5 .

37 Zhao, S., Stone, L, Gao, D., \& He D. (2018). Modelling the large-scale yellow fever outbreak in Luanda, Angola, and the impact of vaccination . PLoS Neglect. Trop. Dis., 12(1).

\author{
У.Т. Мустафа ${ }^{1,2}$, Э. Хинжал ${ }^{1}$, А. Юсуф ${ }^{2,3}$, С. Куреши ${ }^{4}$, \\ Т. Санлидаг ${ }^{1}$, С.М. Мухаммад ${ }^{1}$, Б. Каймакамзаде ${ }^{1}$, Н. Гокбулут ${ }^{1}$ \\ ${ }^{1}$ Таяу Шызыс университеті, Никосия, Түркия; \\ 2 Дуце федералды университеті, Нигерия; \\ ${ }^{3}$ Бируни университеті, Стамбул, Түркия; \\ ${ }^{4}$ Мехран инженерлік-технологиялық университеті, Джамшоро, Пәкістан;
}

\title{
COVID-19-дың берілу динамикасы мен бақылау стратегиясы: модельді зерттеу
}

\begin{abstract}
Бұл зерттеуде халықтың осал топтарының масканы тағуы және әлеуметтік ара қашықтықты сақтаудың әсерін бағалау, пациенттерді карантин мен ауруханаға жатқызуды қамтитын математикалық модель ұсынылған. Модель параметрлері Түркияда 2020 жылдың 11 наурызынан 10 қазанына дейін зертханалық расталған COVID-2019 жағдайларын қолдана отырып бағаланды және модельге бейімделді. Дәрежелік корреляцияның ішінара коэффициенті модельдің сезімталдығын негізгі көбею санымен және жауап беру функциясы ретінде инфекция жылдамдығымен талдау үшін қолданылды. Сезімталдықты талдау нәтижелері COVID-19 инфекциясын тиімді бақылаудың маңызды параметрлері карантиндегі адамдардың қалпына келу жылдамдығы $\left(\delta_{1}\right)$, ауруханаға жатқызылған адамдардың қалпына келу жылдамдығы $\left(\delta_{4}\right)$ және жұқпаның берілу жылдамдығы $(\beta)$ екенін көрсетті. Модельдеудің кейбір нәтижелері модельден кездейсоқ таңдалған екі түрлі биологиялық параметрлердің функциясы ретінде негізгі репродуктивті санға қатысты торлы графиктер арқылы алынады. Соңында, модель динамикасын сандық модельдеу әр айнымалы бөлімдеріндегі инфекциялар саны уақыт өте келе азайып, ауруға шалдыққан адамдардың көбеюіне әкелетінін көрсетті. Бұл індет жұқтырған адамдардан аулақ болу, әлеуметтік арақашықтықты сақтау, маска кию және т.б. талаптарды орындау COVID-19 инфекциясының таралуын болдырмау немесе азайту үшін өте маңызды екенін білдіреді.
\end{abstract}

Kiлm сөздер: COVID-19, математикалық модельдеу, базалық репродуктивті сан, берілу динамикасы, сезімталдықты талдау. 


\author{
У.Т. Мустафа ${ }^{1,2}$, Э. Хинжал ${ }^{1}$, А. Юсуф ${ }^{2,3}$, С. Куреши ${ }^{4}$, \\ Т. Санлидаг ${ }^{1}$, С.М. Мухаммад ${ }^{1}$, Б. Каймакамзаде ${ }^{1}$, Н. Гокбулут ${ }^{1}$ \\ ${ }^{1}$ Ближсневосточный университет, Никосия, Туриия; \\ ${ }^{2}$ Федеральный университет Дуие, Нигерия; \\ ${ }^{3}$ Университет Бируни, Стамбул, Туриия; \\ ${ }^{4}$ Мехранский университет инженерии и технологий, Джамшоро, Пакистан
}

\title{
Динамика передачи и стратегии контроля COVID-19: модельное исследование
}

\begin{abstract}
В статье предложена математическая модель, которая включает карантин и госпитализацию пациентов, чтобы оценить влияние социального дистанцирования и ношение маски среди уязвимых групп населения. Параметры модели оценивались и подгонялись к модели с использованием лабораторно подтвержденных случаев COVID-19 в Турции с 11 марта по 10 октября 2020 г. Частичный коэффициент ранговой корреляции использован для проведения анализа чувствительности модели с базовым числом репродукции и скорости заражения как функции ответа. Результаты анализа чувствительности показывают, что наиболее важными параметрами для эффективного контроля за инфекцией COVID-19 являются скорость выздоровления лиц, находящихся на карантине $\left(\delta_{1}\right)$, скорость выздоровления госпитализированных лиц $\left(\delta_{4}\right)$ и скорость передачи инфекции $(\beta)$. Некоторые результаты моделирования получены с помощью сеточных графиков относительно основного репродуктивного числа как функции двух различных биологических параметров, случайно выбранных из модели. Наконец, численное моделирование динамики модели показало, что количество инфекций из отделов каждой переменной состояния уменьшается со временем, что вызывает увеличение числа восприимчивых людей. Это означает, что избегание контактов с инфицированными людьми посредством адекватного понимания социального дистанцирования и ношения лицевых масок жизненно важно для предотвращения или уменьшения распространения инфекции COVID-19.
\end{abstract}

Ключевые слова: COVID-19, математическое моделирование, базовое репродуктивное число, динамика передачи, анализ чувствительности. 